\title{
Investigations on boron levels in drinking water sources in China
}

\author{
Ren-ji Xu • Xiao-ru Xing • Qun-fang Zhou • \\ Gui-bin Jiang · Fu-sheng Wei
}

Received: 19 January 2009 / Accepted: 6 April 2009 / Published online: 15 May 2009

(C) Springer Science + Business Media B.V. 2009

\begin{abstract}
To evaluate boron contamination of public drinking water in China, both dissolved and total boron contents in 98 public drinking water sources from 49 cities, 42 brands of bottled water samples from supermarkets in several cities, and 58 water samples from boron industrial area were measured by inductively coupled plasma-mass spectrometry (ICP-MS). Our experimental results showed that boron existed in public drinking water sources mainly in dissolved status with total
\end{abstract}

Electronic supplementary material The online version of this article (doi:10.1007/s10661-009-0923-8) contains supplementary material, which is available to authorized users.

R.-j. Xu · F.-s. Wei $(\bowtie)$

Dalian Institute of Chemical Physics,

Chinese Academy of Sciences, Dalian,

116023, China

e-mail:weifs@cae.cn

X.-r. Xing · Q.-f. Zhou · G.-b. Jiang

State Key Laboratory of Environmental

Chemistry and Ecotoxicology,

Research Center for Eco-Environmental Sciences,

Chinese Academy of Sciences,

Beijing, 100085, China

F.-s. Wei

China National Environmental Monitoring Center,

Beijing, 100012, China concentrations ranging from 0.003 to $0.337 \mathrm{mg} / \mathrm{L}$ $($ mean $=0.046 \mathrm{mg} / \mathrm{L})$. The mean boron concentrations in mineral and pure bottled water were 0.052 and $0.028 \mathrm{mg} / \mathrm{L}$, respectively. The results obtained in this work showed that there was no health risk on view of boron in public drinking water sources and bottled water. In boron industrial area, boron concentrations in surface water and ground water were $1.28 \mathrm{mg} / \mathrm{L}$ (range $=0.007-3.8 \mathrm{mg} / \mathrm{L})$ and $18.3 \mathrm{mg} / \mathrm{L}$ (range $=0.015-140 \mathrm{mg} / \mathrm{L})$, respectively, which indicated that boron industry caused boron pollution in local water system.

Keywords Boron - Drinking water source • Bottled water $\cdot$ Boron pollution

\section{Introduction}

Boron (B) is a ubiquitous chemical element in nature and has a high affinity for oxygen (Neal et al. 1998; Wyness et al. 2003). So far, over 150 boron minerals have been found all over the world, but only about ten of them have industrial value. Skarn boron deposit (distributing in Fengcheng, Kuandian, Yingkou counties of Liaodong peninsula) and continental salt lake boron deposit (distributing in salt lakes of Tibetan Plateau) are the two typical types of boron mines in China (Zhu and Wang 2007). Both natural and anthropogenic factors can lead to the release of boron into air, 
water, or soil (Neal et al. 1998), resulting in boron contamination in ambient environment. Because of the wide application of borate and boric acid in industrial and other related fields, boron may also be discharged into the riverine environment with the drainage and leachate from mining industry (Akar 2007; Wyness et al. 2003; Adriano et al. 1980). The majority of the Earth's boron occurs in the oceans, with an average concentration of $4.5 \mathrm{mg} / \mathrm{L}$, but varies widely in fresh water (Weast et al. 1985; Coughlin 1998). In Germany, the researchers found that the populations in large cities were exposed to high levels of boron from drinking water (ECETOC 1996; Howe 1998), inducing the potential risks to human health.

Previous studies indicated that over $90 \%$ of boric acid and borax administrated could be absorbed through the gastrointestinal and respiratory tracts of the experimental animals (Hunt 1989; Bai and Hunt 1996; Litovitz et al. 1988). Although low levels of boron may be beneficial to the bone, excessive uptake of boron can cause symptoms such as coarse hair coats, scaly tails, swollen and desquamated pads of the paws, bloody eye discharge, body weight loss and shrunken scrotum (Weir and Fisher 1972; Heindel et al. 1992; Price et al. 1996). Based on the shortand long-term oral exposures to boric acid or borax, it was demonstrated that the male reproductive tract was a consistent target of boron toxicity in laboratory animals (WHO 1998). A recent investigation on boron workers showed that boron exposure might cause the spouses of male workers had a delay in pregnancy and a decrease in live births (Liu et al. 2005). Sexual chromosomes test (FISH test) showed that the chromosome ratio of $\mathrm{Y}$ :X significantly decreased due to boron exposure (Robbins et al. 2008). In view of the accurate assessment of human health under long-term exposure of boron, the investigation on the ambient boron levels is much of significance.

In general, food and water are the main approaches of boron exposure to human. The mean daily intake of boron in the diet was reported to be near $1.2 \mathrm{mg} /$ day for the normal population according to the previous survey (Anderson et al. 1984). Depending on the sources, concen- trations of boron in drinking water vary in wide ranges, wherein most of them are between 0.1 and $0.3 \mathrm{mg} / \mathrm{L}$ (WHO 1998). Bottled water containing high levels of boron may cause significant more boron exposure to those who drink this kind of water (Abke et al. 1997; Allen et al. 1989; Graffmann et al. 1974). The World Health Organization (WHO) suggested the limit value of boron in water be $0.5 \mathrm{mg} / \mathrm{L}$ (WHO 1998). EU also added element boron to its drinking water standard (1 mg/L) (Directive 98/83/EC).

Tap (from public drinking water sources) water and bottled water are the two main sources of drinking water. Lots of data were reported on boron levels in different water sources in many countries over past decades (Coughlin 1998; Gianni and Marina 1988; Butterwick et al. 1989; Murray 1995; Dyer and Caprara 1997; Coughlin 1998; Sayli 1998; NAQUADAT 1986; Barr et al. 1993; Wyness et al. 2003). Besides, the U.S. has done some health risk assessment of boron in its drinking water (Murray 1995). In China, limited data showed that boron concentrations in drinking water from boron industrial area were higher than those from other areas (Xing et al. 2007). In 2005, public drinking water sources served over 650 million people living in counties and cities (Zheng et al. 2007). In addition, sales of bottled water have been increasing continuously in recent years. Statistic data from the international committee for bottled water show that the annual sales volume of bottled water in China was up to 5.5 billion liters in 2000, this data increased to 8.1 billion liters in 2002 (Yang 2004). However, to the best of the authors' knowledge, few data is available on boron concentrations in these different water sources in China. Therefore, a comprehensive study on boron contamination in water is very necessary in view of the possible effect on human health of boron exposure through drinking water. Regarding the common drinking water types, this investigation is performed on boron levels in surface and ground public drinking water sources from 49 cities in China, 45 brands of bottled water from supermarkets, and 58 water samples from a boron industrial area to offer more information on boron levels in public drinking water in China. 


\section{Materials and methods}

\section{Sample collection}

Drinking water sources A total of 98 water samples including 76 surface water and 22 ground water samples were collected from the local public drinking water sources in 49 main cities of China during January-July, 2007. These cities included 30 provincial capitals and 19 other main cities in China (Fig. 1), covering most regions of China. There are 31 cities of the 49 cities located along the valleys of Changjiang, Haihe/Luanhe, Huaihe, Huanghe, Songhuajiang/Liaohe, and Zhujiang. A total of 55 surface water samples were collected from these cities.
Bottled water samples A total of 45 brands of bottled water were purchased randomly from supermarkets in Beijing, Wuhan, Shenyang, Tianjin, and Kunming. The bottled water samples included 21 homemade mineral water, 21 homemade pure water samples, two mineral water imported from France, and one from America.

Water samples from boron industrial area Drainage and leachate containing boron from mining industries are the main anthropogenic sources of boron. The typical boron industrial area studied here is Kuandian County, Liaoning Province. Boron mineral reserves there are up to 30 million tons, 15 million tons of the total reserves have commercial value, which account

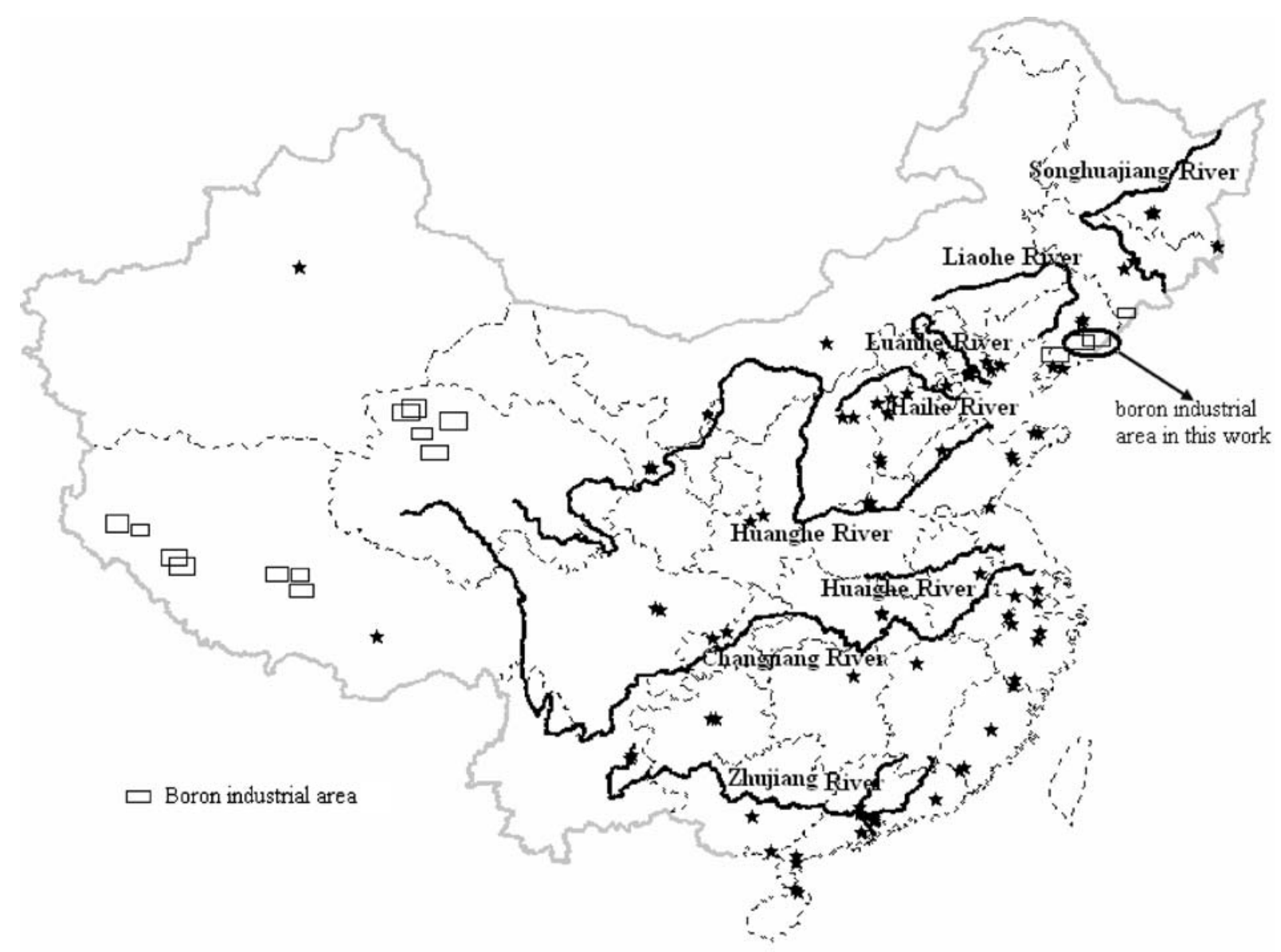

Fig. 1 Sampling sites of dinking water sources in China 


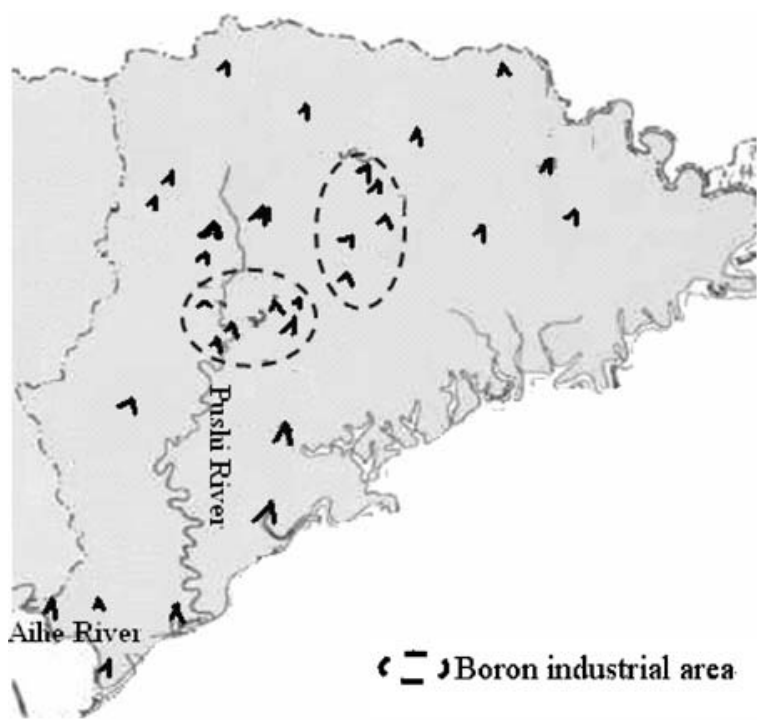

Fig. 2 Sampling sites in a boron industrial area and the ambient area in Kuandian County

for $40 \%$ and $60 \%$ of the gross reserves and recovery of the whole country, respectively. A total of $70 \%$ borax and boron acid products in China are from this region. There are two main rivers in this region: Aihe River goes through the south boundary of Kuandian region; and Pushi River flows through the west of Kuandian city. As shown in Fig. 2, a total of 20 surface water samples and 38 ground water samples were collected from boron mining, processing plant and vicinity area (named by exposure sites), and the ambient areas relatively far away from boron industry (named by ambient sites) during April, 2002 to September, 2004. Among these 20 surface water samples, six samples were collected respectively from the upper, middle, and lower reaches of Aihe River and Pushi River.

\section{Reagent}

Boron standard solution (100 mg/L) and internal standard solution (Rh, $10 \mathrm{ppm}$ ) were obtained from National Research Center for Geoanalysis and diluted to desired concentrations. All the standard solutions contained $1 \% \mathrm{HNO}_{3}$ and were stored in polyethylene bottles. Milli-Q water was used through the test process. Nitric acid used in this work was obtained by sub-boiling distillation of guaranteed grade nitric acid.

\section{Instrument}

The quantification analysis of boron was performed on an inductively coupled plasma-mass spectrometry (ICP-MS; Agilent 7500 a series), and $1 \% \mathrm{HNO}_{3}$ was used as the blank. Parameters of ICP-MS were listed in Table 1.

\section{Chemical analysis}

Both total and dissolved boron contents were measured in water samples from public drinking water sources. Each sample was divided into two duplicates of $50 \mathrm{~mL}$. One was acidified to $1 \% \mathrm{HNO}_{3}$ directly for the measurement of total boron concentration and the other was filtered with $0.45 \mu \mathrm{m}$ micro-pore filter, and then acidified to $1 \% \mathrm{HNO}_{3}$ for the analysis of dissolved boron concentration. For fresh water and wastewater samples from boron exposure sites and ambient sites of Kuandian County and bottled water samples, only total boron concentrations were tested after being acidified to $1 \% \mathrm{HNO}_{3}$. The internal standard of $\mathrm{Rh}(1 \mu \mathrm{g} / \mathrm{mL})$ was loaded online by the pump in the introducing system of ICP-MS during analysis.

Table 1 Optimized parameters of ICP-MS

\begin{tabular}{ll}
\hline Parameters & Optimized values \\
\hline RF power $(\mathrm{W})$ & 1,360 \\
RF matching $(\mathrm{V})$ & 1.55 \\
Sample depth $(\mathrm{mm})$ & 7.7 \\
Torch-H $(\mathrm{mm})$ & 0.2 \\
Torch-V $(\mathrm{mm})$ & 0 \\
Carrier gas $(\mathrm{L} / \mathrm{min})$ & 1.14 \\
Peripump1 $(\mathrm{rps})$ & 0.3 \\
S/C temp $\left({ }^{\circ} \mathrm{C}\right)$ & 2 \\
Extract1 & -103 \\
Extract2 & -13 \\
AMU gain & 126 \\
AMU off set & 127 \\
Axis gain & 0.991 \\
Axis off & 0.01 \\
QP bias & 2 \\
\hline
\end{tabular}


Table 2 Boron concentrations in public drinking water sources $(\mathrm{mg} / \mathrm{L})$

\begin{tabular}{lllllllll}
\hline & Status & Number & Range & Mean & GM & $\begin{array}{l}10 \% \\
\text { percentile }\end{array}$ & $\begin{array}{l}50 \% \\
\text { percentile }\end{array}$ & $\begin{array}{l}90 \% \\
\text { percentile }\end{array}$ \\
\hline Water source & Total & 98 & $0.003-0.337$ & 0.046 & 0.026 & 0.007 & 0.024 & 0.097 \\
& Dissolved & 98 & $0.002-0.333$ & 0.045 & 0.026 & 0.007 & 0.024 & 0.103 \\
Surface water source & Total & 76 & $0.003-0.246$ & 0.040 & 0.023 & 0.006 & 0.023 & 0.089 \\
& Dissolved & 76 & $0.002-0.240$ & 0.039 & 0.022 & 0.006 & 0.022 & 0.089 \\
Ground water source & Total & 22 & $0.007-0.337$ & 0.068 & 0.043 & 0.020 & 0.046 & 0.143 \\
& Dissolved & 22 & $0.007-0.333$ & 0.068 & 0.042 & 0.016 & 0.046 & 0.130 \\
\hline
\end{tabular}

\section{Results and discussion}

Evaluation of the analytical method

As a popular elemental analysis instrument, ICPMS is widely used in the measurement of various inorganic elements in environmental samples because of its high sensitivity and wide linear range (from several nanograms per liter to hundreds of milligrams per liter). Based on this analytical system, the spiked recoveries of boron in the environmental samples are in the range of $103-105 \%$ with the RSD of $3.6 \%$. The correlation coefficient of calibration curve was 0.9999 and the detected limit of boron was $0.0002 \mathrm{mg} / \mathrm{L}$, which ensured the analysis of trace levels of boron in environment samples. Boron levels in the drinking water were all successfully analyzed by ICP-MS herein.

\section{Boron concentrations in drinking water sources}

Generally, boron cannot be removed during water treatment, so boron levels in drinking water sources may directly reflect human exposure to boron through drinking water. Total and the dissolved boron concentrations in 98 water samples from the public drinking water sources of 49 cities in China were determined and the results are summarized in Table 2. It can be found that boron concentrations range from 0.003 to $0.337 \mathrm{mg} / \mathrm{L}$ with the mean level of $0.046 \mathrm{mg} / \mathrm{L}$. The highest total boron concentrations in surface water $(0.246 \mathrm{mg} / \mathrm{L})$ and ground water $(0.337 \mathrm{mg} / \mathrm{L})$ were from Jinan, Shandong province and Beihai, Guangxi province, respectively. The wide use of boron fertilizer and boron-containing commodities may cause high boron in water sources in these two regions. There is no significant difference between total boron concentrations and the dissolved ones, indicating that boron mainly exists in dissolved status. Ground water has relatively higher boron concentration (mean level $=0.068 \mathrm{mg} / \mathrm{L}$ ) than surface water (mean level $=0.040 \mathrm{mg} / \mathrm{L}$ ). Geological factors such as rock weathering and soil leaching may cause high boron level in ground water. Generally, boron concentrations in all tested water samples are below boron standard for public drinking water source $(0.5 \mathrm{mg} / \mathrm{L})$ and hygiene standard of drinking water $(0.5 \mathrm{mg} / \mathrm{L})$ of China, which confirms the safety of these drinking water sources for human health in view of boron.

Based on the comparison of the mean boron concentrations in surface drinking water sources of cities along six valleys, it can be found that boron levels are in the order of Huanghe $>$ Huaihe > Haihe/Luanhe > Changjiang > Songhuajiang/Liaohe $>$ Zhujiang (Table 3). Cities

Table 3 Boron concentrations in cities along different valleys (mg/L)

\begin{tabular}{lccccccc}
\hline Valley & Number & Min. & Max. & Mean & $\begin{array}{l}10 \% \\
\text { percentile }\end{array}$ & $\begin{array}{l}50 \% \\
\text { percentile }\end{array}$ & $\begin{array}{l}90 \% \\
\text { percentile }\end{array}$ \\
\hline Changjiang & 12 & 0.010 & 0.194 & 0.043 & 0.011 & 0.029 & 0.054 \\
Haihe/Luanhe & 23 & 0.003 & 0.239 & 0.043 & 0.017 & 0.035 & 0.050 \\
Huaihe & 1 & 0.091 & 0.091 & 0.091 & 0.091 & 0.091 & 0.091 \\
Huanghe & 5 & 0.007 & 0.246 & 0.143 & 0.007 & 0.145 & 0.246 \\
Songhuajiang/Liaohe & 5 & 0.009 & 0.024 & 0.017 & 0.009 & 0.016 & 0.024 \\
Zhujiang & 9 & 0.006 & 0.046 & 0.017 & 0.006 & 0.014 & 0.046 \\
\hline
\end{tabular}


along Huanghe valley have the highest boron concentration in their drinking water sources with the highest concentration up to $0.246 \mathrm{mg} / \mathrm{L}$, and the second is Huaihe valley. The lowest boron concentration of drinking water sources occurs in cities along Zhujiang valley. In nature, boron levels in surface water mainly depend on the process of rock weathering and soil leaching. There are similar decreasing trends for boron concentrations in soils from west to east and from north to south in China, which is consistent with boron concentration alterations in public drinking water sources along six valleys described above.

Globally, boron concentrations in both surface water and ground water can vary substantially depending on different geographic regions (Table 4). Most of boron concentrations in fresh water are less than $0.1 \mathrm{mg} / \mathrm{L}$; however, in areas with boronrich soils, boron concentration in surface water is up to $26 \mathrm{mg} / \mathrm{L}$ (WHO 1998). In 1987, US National Inorganics and Radionuclides Survey (NIRS) reported the mean boron level in 989 public water supplies was $0.15 \mathrm{mg} / \mathrm{L}$, with the 90th percentile at approximately $0.4 \mathrm{mg} / \mathrm{L}$ (Coughlin 1998). The study on boron in 76 raw water samples from rivers in US from 1984 to 1993 showed that the median value was $0.10 \mathrm{mg} / \mathrm{L}$ (Dyer and Caprara 1997). Barbara and Milby summarized the results of boron contents in ground water from the Southeastern Sacramento valley aquifer, California, and found that the range of boron concentration of 31 water samples was $0.012-1.1 \mathrm{mg} / \mathrm{L}$, with a median of $0.042 \mathrm{mg} / \mathrm{L}$ (Barbara and Milby 2001). The highest boron concentrations of samples from Europe, Canada, and Chile all exceeded $1 \mathrm{mg} / \mathrm{L}$ (NAQUADAT 1986; ECETOC 1996; Abke et al. 1997; Wyness et al. 2003; Diaconu et al. 2008). Boron levels in surface water have been investigated in detail in different countries of Europe (Wyness et al. 2003). Comparison of boron concentrations in surface water sources from different countries including Asia, Africa, America, and Europe shows that Portugal has the highest mean of boron levels in surface water and Argentina has the highest mean of boron concentrations in ground water. But in the drying areas of Chile, boron concentrations in both surface water and ground water are much higher than those in other regions (Yamasaki and Hata 2000). Results ob- tained herein indicate that boron levels in public water sources of main cities in China are generally at the same level as or slightly lower than those in most of other countries in the world.

Boron concentrations in bottled water of China

As another important drinking water source, bottled water is becoming more and more popular in the daily life. Trace elements in bottled water especially for mineral water are thought to be beneficial for human health. However, the guild regulations are still not normative for the levels of most of the trace elements including boron. It is thus of much significance to investigate boron levels in bottled water. The results listed in Table 5 shows that boron concentrations in homemade bottled water are in the range of $0.0002-$ $0.705 \mathrm{mg} / \mathrm{L}$, which is lower than those previously reported in other countries (Abke et al. 1997; Graffmann et al. 1974; Allen et al. 1989; Misund et al. 1999; Güler 2007). Boron concentrations in bottled water imported from France and U.S. range from 0.009 to $0.037 \mathrm{mg} / \mathrm{L}$, which are at the same level as those made in China. In addition, boron levels in mineral water are slightly higher than those in pure water. For 42 brands of bottled water produced in China, only one exceed the boron standard of drinking water $(0.5 \mathrm{mg} / \mathrm{L})$. Generally, the bottled water is safe for human health based on the boron levels determined herein.

\section{Boron contamination status in water of boron} industrial area

Boron intakes through drinking water in populations residing in boron industrial areas were generally much higher than those in other areas (Cöl and Cöl 2003). Boron concentrations in surface and ground water samples from the industrial area in Kuandian County, Liaoning Province were measured in this work. The results shown in Table 6 indicate that the means of boron concentrations in surface and ground water from exposure sites are 1.28 and $18.3 \mathrm{mg} / \mathrm{L}$, respectively, which are 32.0 and 269 times higher than those in public drinking water sources described above. The overall mean of boron concentration 


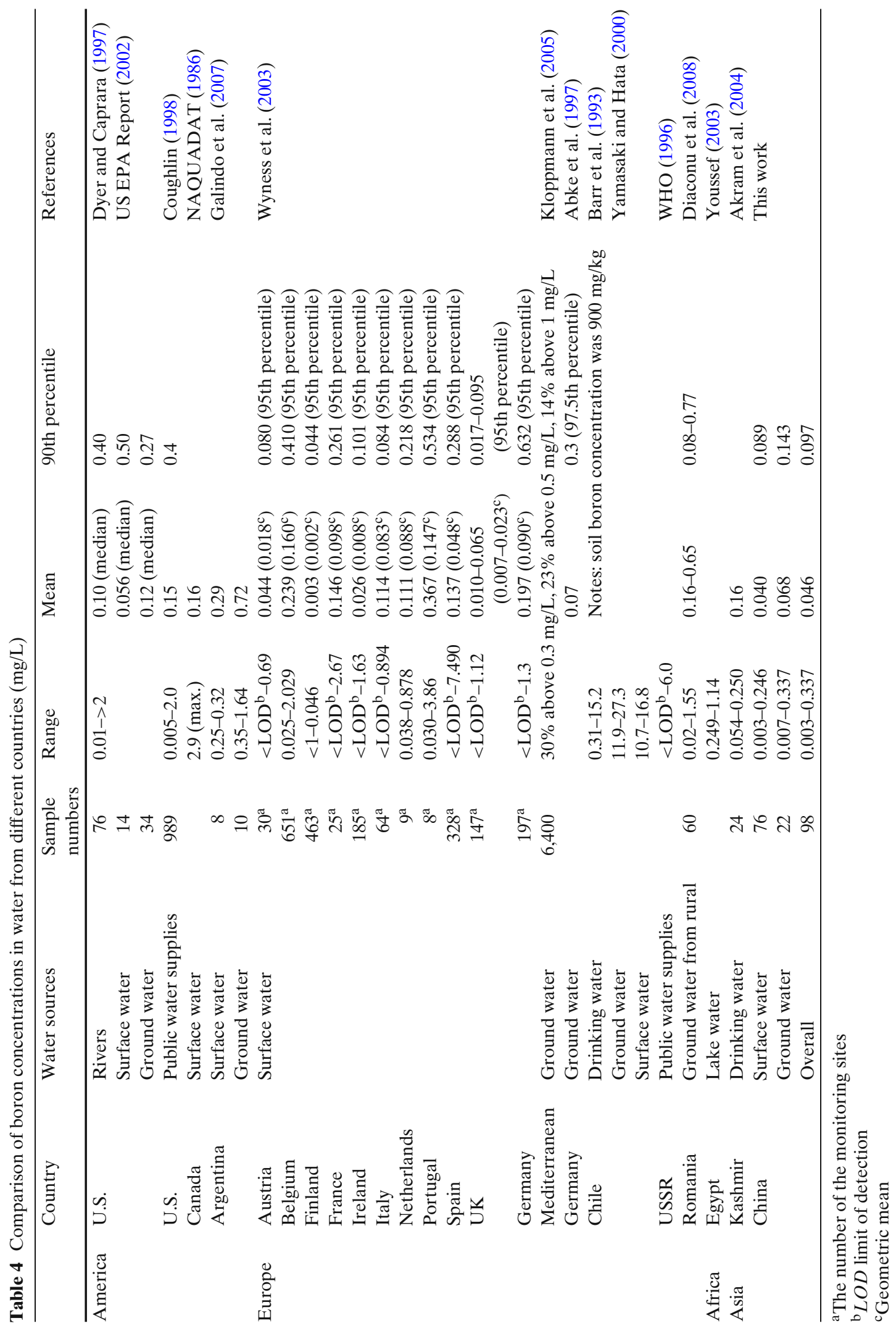


Table 5 Boron concentrations in bottled water samples produced in different countries $(\mathrm{mg} / \mathrm{L})$

\begin{tabular}{llcclllll}
\hline & Number & Min & Max & Mean \pm SD & $\begin{array}{l}10 \% \\
\text { percentile }\end{array}$ & Median & $\begin{array}{l}90 \% \\
\text { percentile }\end{array}$ & References \\
\hline Mineral water & 21 & 0.0002 & 0.705 & $0.052 \pm 0.151$ & 0.0002 & 0.012 & 0.062 & This work \\
Pure water & 21 & 0.0002 & 0.242 & $0.028 \pm 0.056$ & 0.0002 & 0.007 & 0.050 & Abke et al. (1997) \\
Germany & & & 2.1 & 0.36 & & Graffmann et al. (1974) \\
Germany & & 0.02 & 3.23 & 0.5 & & Allen et al. (1989) \\
America & & $<0.005$ & 4.35 & 0.75 & & 0.092 & Misund et al. (1999) \\
Europe & 56 & $<0.005$ & 10.1 & & & & Güler (2007) \\
Turkish & 60 & 0.004 & 10.0 & $0.137 \pm 0.203$ & & & &
\end{tabular}

in surface and ground water samples from exposure sites is $15.0 \mathrm{mg} / \mathrm{L}$, which is at the same level as those in Turkey (Cöl and Cöl 2003; Sayli 1998). Obviously, boron levels in ground water are much higher than those in the surface water. Eight ground water and two surface water samples have boron concentrations exceeding $1.0 \mathrm{mg} / \mathrm{L}$. The highest value is $140 \mathrm{mg} / \mathrm{L}$, which is 46.7 times higher than boron standard for agricultural irrigation of China (3 mg/L). Total 14 (53.8\%) water samples from the exposure sites have boron concentrations over $0.5 \mathrm{mg} / \mathrm{L}$, indicating the possible risk may be induced to human health by boron exposure through drinking water in this area. For the ambient sites, it can be found that the mean boron levels are 0.123 and $0.008 \mathrm{mg} / \mathrm{L}$ for surface water and ground water, respectively. They are clearly lower than those from exposure sites and equal to the values in public drinking sources of other cities described above and the ambient area in Turkey (Sayli 1998). However, two samples contain boron concentrations were detected slightly higher than boron standard for drinking water, which should be paid attention for our future research.

The monthly monitoring results of boron concentrations in the drinking water well located in a boron processing plant during June to September, 2004 were 4.21, 115, 140, and $69.5 \mathrm{mg} / \mathrm{L}$, respectively. As we all know, the period from July to September is the raining season in this region (Xing et al. 2007), and the studied well is only about $5 \mathrm{~m}$ away from the waste ore. The rain leachate containing high levels of boron may pollute the well water, leading to the obvious alterations in boron levels, whereas boron concentration in the mountain spring collected in the back of the same boron processing plant is as low as $0.1 \mathrm{mg} / \mathrm{L}$, indicating boron contamination in some locations origins from point sources.

The comparisons of boron levels in upper, middle, and lower reaches of Aihe River and Pushi River show the increasing boron levels from the upper streams to middle and lower reaches of these rivers (Table 7). The boron industrial

Table 6 Boron concentrations in water samples from boron industrial area $(\mathrm{mg} / \mathrm{L})$

\begin{tabular}{|c|c|c|c|c|c|c|c|c|}
\hline & & Sample sources & Number & Range & Mean \pm SD & GM & Median & References \\
\hline \multirow[t]{4}{*}{ China } & \multirow{2}{*}{$\begin{array}{l}\text { Surface } \\
\text { water }\end{array}$} & Exposure sites & 5 & $0.007-3.8$ & $1.28 \pm 1.79$ & 0.124 & 0.039 & \multirow[t]{4}{*}{ This work } \\
\hline & & Ambient sites & 15 & $0.005-0.67$ & $0.123 \pm 0.228$ & 0.024 & 0.009 & \\
\hline & \multirow{2}{*}{$\begin{array}{l}\text { Ground } \\
\text { water }\end{array}$} & Exposure sites & 21 & $0.015-140$ & $18.3 \pm 39.7$ & 1.17 & 0.570 & \\
\hline & & Ambient sites & 17 & $0.002-0.027$ & $0.008 \pm 0.007$ & 0.007 & 0.006 & \\
\hline \multirow[t]{2}{*}{ Turkey } & \multirow{2}{*}{$\begin{array}{c}\text { Drinking } \\
\text { water }\end{array}$} & Ambient sites & - & $0.05-0.45$ & & & & \multirow[t]{2}{*}{ Sayli (1998) } \\
\hline & & Exposure sites & - & $0.7-29$ & & & & \\
\hline Turkey & $\begin{array}{l}\text { Ambient } \\
\text { water }\end{array}$ & $\begin{array}{l}\text { Surface, ground and } \\
\text { fountain water }\end{array}$ & - & $2.05-29$ & $10.2 \pm 4.08$ & & & Cöl and Cöl (2003) \\
\hline China & $\begin{array}{c}\text { Drainage } \\
\text { water }\end{array}$ & & 8 & $0.99-928$ & $144 \pm 320$ & 21.9 & 15.7 & This work \\
\hline Turkey & $\begin{array}{c}\text { Drainage } \\
\text { water }\end{array}$ & & 3 & $16-390$ & & & & Okay et al. (1985) \\
\hline
\end{tabular}


Table 7 Boron concentrations in Aihe River and Pushi River in Kuandian County (mg/L)

\begin{tabular}{llll}
\hline River & $\begin{array}{l}\text { Upper } \\
\text { reaches }\end{array}$ & $\begin{array}{l}\text { Middle } \\
\text { reaches }\end{array}$ & $\begin{array}{l}\text { Lower } \\
\text { reaches }\end{array}$ \\
\hline Aihe River & 0.008 & 0.51 & 0.50 \\
Pushi River & 0.022 & 3.8 & 2.56 \\
\hline
\end{tabular}

activities may contribute to boron contamination therein. Similar results were obtained in the study on Simav River, a main river receiving discharge from boron mines in Turkey, wherein boron concentrations in the river were $0-0.5 \mathrm{mg} / \mathrm{L}$ before entering the boron mining region and increased to $4 \mathrm{mg} / \mathrm{L}$ after receiving boron discharge (Okay et al. 1985). These findings indicate that landfill leaching and waste water discharge from human activities may cause high boron in water and should be of concern.

Boron discharge regulations in wastewater can seldom be found in most countries in the world. The direct discharge of wastewater containing high levels of boron may seriously pollute the ambient environment, which should draw much attention. Boron concentrations in wastewater from boron mining and processing plants determined herein range from 0.99 to $928 \mathrm{mg} / \mathrm{L}$ with an average of $144 \mathrm{mg} / \mathrm{L}$, which is at the same level as those in Turkey (Table 6; Okay et al. 1985). Only three of eight samples have boron concentrations lower than the standard for boron discharge in wastewater $(10 \mathrm{mg} / \mathrm{L})$ enacted by Japan in 2001 . Particularly, boron levels in two samples even exceed $100 \mathrm{mg} / \mathrm{L}$, which may offer a great threat to the environment through direct discharge. The minimum value of $0.99 \mathrm{mg} / \mathrm{L}$ is detected in a sample from bath discharge, which is the only one satisfying the boron standard for agricultural irrigation $(3.0 \mathrm{mg} / \mathrm{L})$. Discharge of this kind of wastewater can definitely cause boron pollution in surface and ground water in this area.

\section{Risk assessment of boron exposure through drinking water}

Based on the comparison of the studied drinking water sources herein, it is clear that similar boron levels are found in the public drinking water sources of main cities, bottled water and the

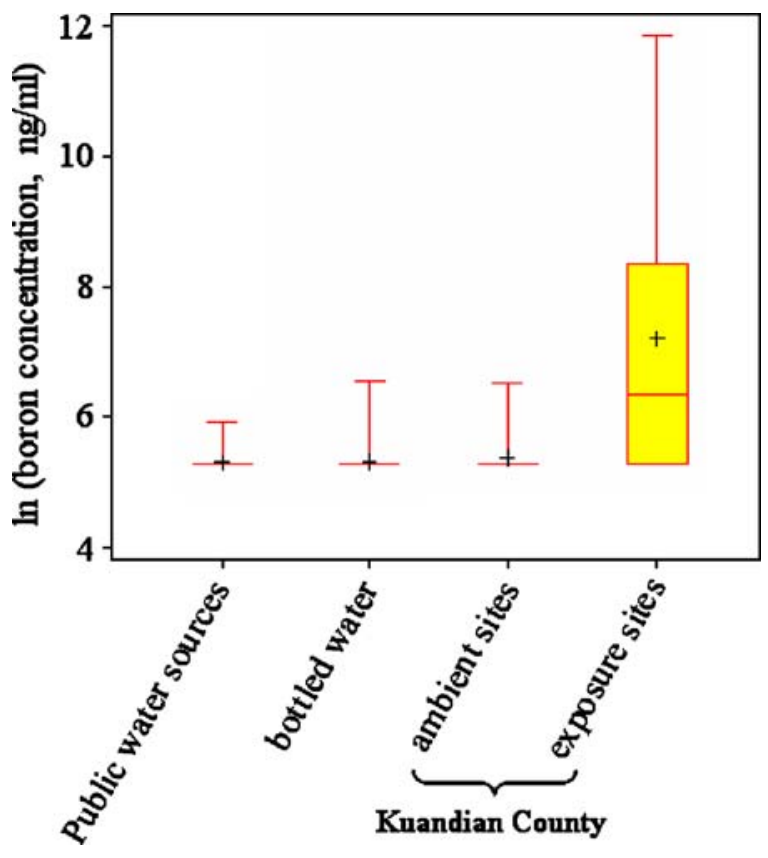

Fig. 3 Comparison of boron concentrations in different kinds of water in China

ambient sites in boron industrial area in China (Fig. 3). These values are generally below boron standard in drinking water $(0.5 \mathrm{mg} / \mathrm{L})$, which is concluded that boron in China general drinking water sources would not be expected to have any health risk to the public. However, based on the results obtained in water sources of boron mining, processing plants and vicinity area, it shows the obviously high boron pollution there. The limit value for daily boron intake suggested by WHO is $13 \mathrm{mg} /$ day (WHO 1998). If the individual daily drinking water volume is presumed to be $2 \mathrm{~L}$, boron concentration in the drinking water should be lower than $6.5 \mathrm{mg} / \mathrm{L}$. Six of 26 samples from boron exposure sites in this work have boron concentrations exceeding this value, which may induce potential hazards to human health through drinking this kind of water. Previous studies confirmed that male workers in this area have relatively higher probabilities of female offspring (Robbins et al. 2008). In conclusion, although most of drinking water in China is safe for human health, boron levels in some local water systems in boron industrial areas should still be cared about. 


\section{Conclusions}

Based on the investigation on boron levels in public drinking water sources and bottled water in China and the contamination status of boron in water from boron industrial area, we can find universal occurrence of this element. In drinking water sources, boron mainly exists in dissolved form and its concentration is at the same level as those in other countries. Boron concentrations in 42 brands of bottled water from China are at the same level as those from public drinking water sources but lower than those in bottled water reported in America and Europe. Accordingly, levels of boron public drinking water sources and bottled water are safe to human health. However, in boron industrial area, boron levels in surface and ground water are much higher than those in the ambient area and exceed the limit value of relevant standards. Therefore, measures should be taken to improve the drinking water quality of this area. As wastewater boron concentrations exceed boron limit value for agricultural irrigation and may contribute to boron pollution in drinking water sources of this region, some related regulations are necessary to control the wastewater discharge.

\section{References}

Abke, W., Engel, M., \& Post, B. (1997). Contamination of ground and surface water in Germany with boron. Vom Wasser, 88, 257-271.

Adriano, D. C., Page, A. L., Elseewi, A. A., Chang, A. C., \& Straughan, I. (1980). Utilization and disposal of fly ash and other coal residues in terrestrial ecosystems, a review. Journal of Environmental Quality, 9, 333-344.

Akar, D. (2007). Potential boron pollution in surface water, crop, and soil in the Lower Buyuk Menderes Basin. Environmental Engineering Science, 24(9), 1273-1279. doi:10.1089/ees.2006.0218.

Akram, M., Khattak, N., Qureshi, A., Iqbal, A., Ullah, K., \& Qureshi, I. (2004). Neutron induced radiography in the determination of boron in drinking water. Journal of Radioanalytical and Nuclear Chemistry, 261(2), 429-435, (7).

Allen, H. E., Halley-Hendeerson, M. A., \& Hass, C. N. (1989). Chemical composition of bottled mineral water. Archives of Environmental Health, 44(2), 102-116.

Anderson, D. L., Cunningham, W. C., \& Lindstrom, T. R. (1984). Concentrations and intakes of H, B, S, K, Na,
$\mathrm{Cl}$ and $\mathrm{NaCl}$ in foods. Journal of Food Composition and Analysis, 7(1-2), 59-82.

Bai, Y., \& Hunt, C. D. (1996). Absorption and distribution of boron in rats following a single oral administration of boron. In Proceedings of the North Dakota academy of science (Vol. 50, p. 53).

Barbara, J., \& Milby, D. (2001). Ground-water quality in the southeastern Sacramento Valley Aquifer, California 1996. U.S. Geological Survey, Water-Resources Investigations Report 01-4125, Sacramento, California.

Barr, R. D., Clarke, W. B., Clarke, R. M., Venturelli, J., Norman, G. R., Downing, R. G., et al. (1993). Regulation of lithium and boron levels in normal human blood, environmental and genetic considerations. The Journal of Laboratory and Clinical Medicine, 121(4), 614-619.

Butterwick, L., de Oude, N., \& Raymond, K. (1989). Safety assessment of boron in aquatic and terrestrial environments. Ecotoxicology and Environmental Safety, 17(3), 339-371. doi:10.1016/0147-6513(89)90055-9.

Cöl, M., \& Cöl, C. (2003). Environmental boron contamination in waters of Hisarcik area in the $\mathrm{Ku}$ tahya Province of Turkey. Food and Chemical Toxicology, 41(10), 1417-1420. doi:10.1016/S02786915(03)00160-1.

Coughlin, J. R. (1998). Source of human exposure overview of water supplies as sources of boron. $B i$ ological Trace Element Research, 66(1-3), 87-100. doi:10.1007/BF02783129.

Diaconu, D., Nastase, V., Nănău, M., Nechifor, O., \& Nechifor, E. (2008). Estimation of boron concentration in some drinking water samples of rural areas. Journal of Preventive Medicine, 16(1-2), 77-84.

Dyer, S. D., \& Caprara, R. J. (1997). A method for evaluating consumer product ingredient contributions to surface and drinking water: Boron as a test case. Environmental Toxicology and Chemistry, 16(10), 2070-2081. doi:10.1897/1551-5028(1997)016< 2070:AMFECP>2.3.CO;2.

ECETOC (1996). Ecotoxicology of some inorganic borates. ECETOC Special Report No. 11. Brussels, European Centre for Ecotoxicology and Toxicology of Chemicals.

Galindo, G., Sainato, C., Dapeña, C., Fernández-Turiel, J. L., Gimeno, D., Pomposiello, M. C., et al. (2007). Surface and groundwater quality in the northeastern region of Buenos Aires Province, Argentina. Journal of South American Earth Sciences, 23(4), 336-345. doi:10.1016/j.jsames.2007.02.001.

Gianni, T., \& Marina, C. (1988). Boron content in freshwaters of Northern Italy. Water, Air, and Soil Pollution, 38(3-4), 409-417. doi:10.1007/BF00280769.

Graffmann, G., Kuzel, P., \& Noslter, H. (1974). The determination of boron traces in surface and drinking water: A comprehensive investigation in the Federal Republic of West Germany. Chemiker Zeiungt, 98, 499-504.

Güler, C. (2007). Characterization of Turkish bottled waters using pattern recognition methods. Chemometrics and Intelligent Laboratory Systems, 86(1), 86-94. doi:10.1016/j.chemolab.2006.08.009. 
Heindel, J. J., Price, C. J., \& Field, E. A. (1992). Developmental toxicity of boric acid in mice and rats. Fundamental and Applied Toxicology, 18(2), 266-277. doi:10.1016/0272-0590(92)90055-M.

Howe, P. D. (1998). A review of boron effects in the environment. Biological Trace Element Research, 66(1-3), 153-166. doi:10.1007/BF02783135.

Hunt, C. D. (1989). Dietary boron modified the effects of magnesium and molybdenum on mineral metabolism in the cholecalciferol-deficient chick. $B i$ ological Trace Element Research, 22(2), 201-220. doi:10.1007/BF02916650.

Kloppmann, W., Bianchini, G., Charalambides, A., Dotsika, E., Guerrot, C., Klose, P., et al. (2005). Boron contamination of Mediterranean groundwater resources: Extent, sources and pathways elucidated by environmental isotopes. Geophysical Research Abstracts, 7, 10162. http://www.cosis.net/abstracts/ EGU05/10162/EGU05-J-10162.pdf. Accessed 16 January 2009.

Litovitz, T. L., Klein-Schwartz, W., Oderda, G. M., \& Schmitz, B. F. (1988). Clinical manifestation of toxicity in a series of 784 boric acid ingestions. The American Journal of Emergency Medicine, 6(3), 209-213. doi:10.1016/0735-6757(88)90001-0.

Liu, P., Wang, C. L., Hu, J. F., Xun, L., Robbins, W. A., Wu, G. P., et al. (2005). Preliminary study on pregnancy outcome of spouses of boron workers. Chinese Journal of Public Health (Chinese), 21(5), 567-568.

Misund, A., Frengstad, B., Siewers, U., \& Reimann, C. (1999). Variation of 66 elements in European bottled mineral waters. The Science of the Total Environment, 243-244, 21-41. doi:10.1016/S0048-9697(99)00307-1.

Murray, F. J. (1995). A human health risk assessment of boron (boric acid and borax) in drinking water. Regulatory Toxicology and Pharmacology, 22(3), 221-230. doi:10.1006/rtph.1995.0004.

National Water Quality Data Bank (NAQUADAT) (1986). Environment Canada, inland waters directorate. Water Quality Branch, Ottawa.

Neal, C., Foxb, K. K., \& Harrowa, M. L. (1998). Boron in the major UK rivers entering the North Sea. The Science of the Total Environment, 210-211, 41-51. doi:10.1016/S0048-9697(98)00043-6.

Okay, O., Güçlü, H., Soner, E., \& Balkaş, T. (1985). Boron pollution in the Simav River, Turkey and various methods of boron removal. Water Research, 19(7), 857-862. doi:10.1016/0043-1354(85)90143-5.

Price, C. J., Marr, M. C., Myeos, C. B., Seely, J. C., Heindel, J. J., \& Schwetz, B. A. (1996). The developmental toxicity of boric acid in rabbits. Fundamental and Applied Toxicology, 34(2), 176-187. doi:10.1006/faat.1996.0188.

Robbins, W. A., Wei, F. S., Elashoff, D. A., Wu, G. P., Xun, L., \& Jia, J. (2008). Y:X sperm ratio in boron- exposed men. Journal of Andrology, 29(1), 115-121. doi:10.2164/jandrol.107.003541.

Sayli, B. S. (1998). An assessment of fertility in boronexposed Turkish subpopulations: 2. Evidence that boron has no effect on human reproduction. $B i$ ological Trace Element Research, 66(1-3), 409-22. doi:10.1007/BF02783152.

US EPA Report (2002). Community water system survey 2000. Volume II: Detailed tables and survey methodology. US EPA 815-R-02-005B.

Weast, R. C., Astle, M. J., \& Beyer, W. H. (1985). CRC handbook of chemistry and physics (69th ed., pp. B-77, B-129). Boca Raton: CRC.

Weir, R. J., \& Fisher, R. S. (1972). Toxicologic studies on borax and boric acid. Toxicology and Applied Pharmacology, 23(3), 351-364. doi:10.1016/ 0041-008X(72)90037-3.

WHO (1996). Guidelines for drinking-water quality (2nd ed., Vol. 2). Health criteria and other supporting information. Inorganic constituents and physical parameters. http://www.who.int/entity/water_sanitation_ health/dwq/2edvol2p2b.pdf. Accessed 18 January 2009.

WHO (1998). Environmental health criteria 204: Boron. http://www.inchem.org/documents/ehc/ehc/ehc204.htm. Accessed 18 January 2009.

Wyness, A. J., Parkmana, R. H., \& Nealb, C. (2003). A summary of boron surface water quality data throughout the European union. The Science of the Total Environment, 314-316, 255-269. doi:10.1016/ S0048-9697(03)00106-2.

Xing, X. R., Wu, G. P., Wei, F. S., Wang, C. L., Wei, C., \& Jiang, X. (2007). Daily intake of boron through food and drinking water for people living in different environments. Journal of Environment and Health (Chinese), 24(3), 125-127.

Yamasaki, Y., \& Hata, Y. (2000). Groundwater contamination by arsenic in the world, changes and their factors of concentrations of arsenic and boron in the process of groundwater recharge in the Lower Lluta River Basin, Chile. Journal of Groundwater Hydrology, 42(4), 341-353.

Yang, C. G. (2004). China sugar \& liquor yearbook 2004 industry. Beijing: Economic Times Press.

Youssef, D. H. (2003). Distribution of boron in some Egyptian aquatic environments. Journal of Oceanography, 59(5), 537-544. doi:10.1023/B:JOCE. 0000009584.42526 .16 .

Zheng, B. H., Fu, Q., \& Liu, Y. (2007). Environmental problems and solutions for public drinking water sources in China. Environmental Protection (Chinese), 381(19), 59-61.

Zhu, E. J., \& Wang, E. D. (2007). Boron environmental geochemistry and its environmental response (pp. 383391). Netherlands: Springer. 